IZA DP No. 5436

Business Visits and the Quest for External Knowledge

Massimiliano Tani

January 2011 


\title{
Business Visits and the Quest for External Knowledge
}

\author{
Massimiliano Tani \\ Macquarie University \\ and IZA
}

\section{Discussion Paper No. 5436 \\ January 2011}

\author{
IZA \\ P.O. Box 7240 \\ 53072 Bonn \\ Germany \\ Phone: +49-228-3894-0 \\ Fax: +49-228-3894-180 \\ E-mail: iza@iza.org
}

Any opinions expressed here are those of the author(s) and not those of IZA. Research published in this series may include views on policy, but the institute itself takes no institutional policy positions.

The Institute for the Study of Labor (IZA) in Bonn is a local and virtual international research center and a place of communication between science, politics and business. IZA is an independent nonprofit organization supported by Deutsche Post Foundation. The center is associated with the University of Bonn and offers a stimulating research environment through its international network, workshops and conferences, data service, project support, research visits and doctoral program. IZA engages in (i) original and internationally competitive research in all fields of labor economics, (ii) development of policy concepts, and (iii) dissemination of research results and concepts to the interested public.

IZA Discussion Papers often represent preliminary work and are circulated to encourage discussion. Citation of such a paper should account for its provisional character. A revised version may be available directly from the author. 
IZA Discussion Paper No. 5436

January 2011

\section{ABSTRACT}

\section{Business Visits and the Quest for External Knowledge*}

This paper contributes to existing work on innovation by studying the determinants of various types of interaction between a firm and its external environment. In particular, it focuses on face-to-face interactions carried out through international business visits. The results indicate that accessing external knowledge is a key determinant of the decision to interact, regardless of the chosen form of interaction. Conferences and trade fairs are the interactions with the highest probability of knowledge gain, while visits to new customers and suppliers are those with the lowest. The likelihood of accessing external knowledge is also affected by the type of employer and functional unit involved, and the characteristics of the employee carrying the visit out. The results support that labour mobility aimed at interacting can add to an organisation's efficient use of human resources. As a result, it highlights that cutting travelling budgets to reduce financial expenditures also reduces opportunities to interact and, with it, the access to external knowledge.

JEL Classification: F2, J6

Keywords: external knowledge, face-to-face interactions, international business visits

Corresponding author:

Massimiliano Tani

Department of Economics

Macquarie University

NSW 2109

Australia

E-mail: max.tani@mq.edu.au

\footnotetext{
* This paper is part of a research project funded by ARC grant no. LP 0561107 and the Department of Immigration and Citizenship (DIAC). I thank Stephane Mahuteau for valuable comments, and Gregory Ainsworth and Matias Vaira for excellent research assistance. The usual disclaimer applies.
} 


\section{Introduction}

Research on the sources of innovation and innovation survey data concur that the knowledge used by firms for new products and applications typically exists or is originally developed outside, rather than within, the successful innovator (e.g. Mueller, 1962; March and Simon, 1958; Mansfield, 1968; Rosenberg and Steinmuller, 1988). As a result, a firm can gain an additional leading edge over its competitors by being able to recognise useful external knowledge to be commercially exploited. This ability, commonly referred to as absorptive capacity (e.g. Cohen and Levinthal, 1989; 1990) or dynamic capability (e.g. Teece and Pisano, 1997) by the literature on innovation, can be developed by carrying out $R \& D$, engaging directly in production, and investing in advanced technical training, amongst others. This is possible as these activities facilitate the creation of novel linkages between what the firm already knows and the new information acquired. In turn, these new linkages and information expand the firm's problem-solving capabilities and, as in the development of cognitive skills in an individual, enhance further the firm's absorptive capacity and the potential economic benefits from the enlarged knowledge stock.

This virtuous circle of learning from the external environment, internalisation and reelaboration of knowledge cannot exist without opportunities for interacting with the outside environment (e.g. meeting customers), the professional skills and personal abilities of the people carrying them out, and certain institutional settings that favour easy and speedy twoway communication between the functional units located at the interface with the 'outside world' (e.g. marketing) and those at the core of the firm (e.g. production).

A large literature documents the variety of interactions with the external environment that ultimately have a positive effect on a firm's absorptive capacity: these include formal and informal collaborations with private or government-sponsored research centres like 
universities, laboratories or other agencies, arrangements catering for knowledge transfers like M\&A activity, licensing, joint R\&D, manufacturing or distribution, and the temporary employment of personnel holding key knowledge. These studies, however, tend to identify new knowledge with outcome measures, such as patents or new processes, technologies or managerial practices, that capture only in part activities and choices made by firms in their quest for accessing and exploiting external knowledge. Patents do not account for previous attempts, past failures and other activities that nevertheless enable firms to acquire experience and expertise that proves instrumental in turning a knowledge breakthrough into a commercially successful product or service, even after a substantial time lag. Moreover, it excludes knowledge that is not copyrighted but that still contributes positively to productivity and innovation, like informal exchanges (e.g. Noorderhaven and Harzing, 2008).

In addition, the existing literature on innovation tends to analyse the knowledge outcome of one interaction separately from others that might have been available to the firm. Yet, interactions, especially when costly financially and in management time, are the unlikely result of chance. Firms choose when and how much to interact with the external environment, as well as, most importantly, with whom to interact. Understanding the determinants of such choices appears relevant in the context of globalisation, where firms of all sizes are faced not only with vastly greater opportunities to interact than ever before but also the problem of making strategic choices about which form of interaction to undertake when faced with finite budgets. For firms, higher opportunities to interact also heighten the issue of efficiency in collecting and redistributing knowledge internally across functional units. For governments and their national innovation systems the possibility that interactions result in more knowledge production questions the nature of the existing incentives for such activities. Interaction related costs are currently treated as expenditures, but they might be turn out to be investments in accessing knowledge. 
This paper contributes to existing work on innovation by studying the determinants of various types of interaction between a firm and its external environment. In particular, it focuses on face-to-face interactions carried out through international business visits. These are trips lasting for less than 12 months, due to work-related reasons and paid for by the employer in the country of origin (UN, 1998). Their growth has been continuous despite the availability of other forms of communication, including those by distance mode (Button and Vega, 2008). In 2007, they reached a volume of over 400 million people, or about $7 \%$ of the world's labour force (e.g. IATA, 2007; NBTA, 2009). The interaction types analysed are visits between an employer and (1) other parts of the same organisation, like a subsidiary, a joint venture, or an affiliated organisation; (2) a company within the same supply chain; (3) new potential customers and/or suppliers; (4) conferences or trade fairs. These four categories arise from the answers given by international business visitors to an ad hoc airport survey, which is used as main data source (more on it below).

In addition, for each type of interaction, the paper measures the probability of accessing vital external knowledge, and analyses its determinants. This probability is identified by a 'quasiobjective' measure of knowledge production activity: namely, the interviewee's selfassessment of the counterfactual to what would occur to his/her employer if travel did not take place. This was posed as an open-ended question in the airport survey. About a third of respondents indicate that not travelling leads to a 'loss' of knowledge, like becoming unaware of the industry's latest development or best practice. These answers are used to identify visits aimed at accessing essential external knowledge.

The data used in the empirical analysis come from a survey of 1,982 international business visitors to and from Australia carried out in November 2006. The survey includes information on visitors' demographic and occupational characteristics, the functional unit in which the visitor is employed, the purpose of travel, and the relationship between visiting and visited 
organisations. Australia presents an ideal case to study face-to-face interactions through business visits as its system of mandatory landing and departure cards, matched to the visa application in the case of foreign residents, enable the national statistical office to collect information on the entire population flowing in and out of the country. As this information is accessible for research purposes, it is possible to use it as a benchmark to identify the potential biases of survey samples.

The assumption at the core of this paper is that firms make a choice amongst alternative types of interaction when deciding to engage with the external environment. This prior is supported by the fact that every type of employer, from multinational corporations (MNC) to small and medium-sized enterprises with less than 100 employees (SME), from government to nongovernment organisations (NGO) and universities, make use of visits across all four interaction categories highlighted above. Since the airport survey covers travellers only, visits to another part of the same organisation or to an associated company are used as the reference group.

The results indicate that accessing external knowledge is a key determinant of the decision to interact, regardless of the chosen form of interaction. Conferences and trade fairs are the interactions with the highest probability of knowledge gain (48\%), while visits to new customers and suppliers are those with the lowest (15\%). These estimated probabilities are not insignificant. The likelihood of accessing external knowledge is also affected by the type of employer and functional unit involved, and the characteristics of the employee carrying the visit out. Interestingly, more frequent interactions are associated with a lower likelihood of knowledge gain. The results suggest that the cost to employers for not interacting includes their access to external knowledge.

The rest of the paper is organised as follows. Section 2 reviews the relevant literature. Section 3 presents the data. Section 4 discusses empirical approach and results. Section 5 concludes. 


\section{Interactions through business visits and the access to knowledge}

The existing literature hardly addresses how face-to-face interactions relate to firms' quest to access external knowledge. This reflects the lack and practical difficulty in developing a comprehensive metric capturing all the activities carried out by firms to do so. The most reliable measures are perhaps objective metrics of productive inputs, like R\&D expenditures or the number of scientists and engineers employed, or outcomes, like patents. More recently, innovation surveys have begun collecting information on more subjective measures of knowledge production, like the interviewee's assessment of whether a new process or technology was introduced in a firm, and whether this was new to the firm, the country or the world.

Notwithstanding the challenge of measuring knowledge production, the question of how interacting relates to accessing knowledge is framed by two separate literatures. The first focuses on the role of people's mobility in enacting international knowledge transfers. Here knowledge includes both disembodied features, which make it codifiable and replicable through blueprints, and embodied characteristics, like ability and experience, that are inextricably connected with the individual learning, sharing or using the knowledge (e.g. Polanyi, 1966). Existing and emerging 'human channels' of international knowledge transfer ${ }^{1}$ include international students (e.g. Park, 2004), employees moving institutions and firms or between firms (e.g. Zellner, 2003; Franco and Filson, 2000), and informal and social networks of people (e.g. Dahl and Pedersen, 2004; Singh, 2005). A particular sub-set of this literature focuses on knowledge transfers within the same organisation, generally between the headquarters of a MNC and its subsidiaries carried out through expatriates (e.g. Collings, Scullion, Morley, 2007) but also vice-versa (e.g. Riusala and Suutari, 2004). Less common is

\footnotetext{
${ }^{1}$ Other channels of knowledge transmissions are foreign direct investments and the international trade of goods (e.g. Dowrick and Rogers, 1995).
} 
the study of the role of international business visitors. The few existing analyses have shown that this channel is more effective than long-term relocations in transferring information within MNCs (Minbaeva and Michailova, 2004), and that, at the sectoral level, making a visit has a stronger positive effect on the sending country's multifactor productivity than receiving one (e.g. Dowrick and Tani, 2011).

The second group of studies relevant to analyse the link between interacting and accessing external knowledge focuses on the features that help creating a causal relation between the former and the latter. These features can be reduced to face-to-face communication, spatial proximity, and the duration of the interaction.

There is little doubt that face-to-face interaction is the critical 'first step' in the path leading to a knowledge exchange. Its main feature is to enable participants to communicate directly with each other, to ask questions, and to clarify possible misunderstandings in a timely fashion. This is particularly important when the visitors and the visited do not share the same culture and language, as is often the case for international business visitors. Face-to-face communication is not limited to spoken language but encompasses the other senses (especially vision), and provides context to communication (e.g. firm or soft handshake, facial expressions and reactions to conversation, body movement, gesticulation...) that is essential to develop empathy, if any, with the interlocutor, and vice-versa. Research has shown that even when alternative forms of communication exist (e.g. telephone and emails, videoconferencing), face-to-face interaction remains the most effective because it makes participants decide immediately whether to trust each other (e.g. Gambardella, 1988; Storper and Venables, 2004). If mutual trust is established, then reciprocal understanding and cooperation can increase, as the transaction costs and uncertainty associated with sharing knowledge are lower. This facilitates exchanges of information and tacit knowledge (Hansen, 1999; Amin and Cohendet, 2004). It also helps the creation of 'social capital' and networks 
(Portes, 1998; Burt, 1997). When there is trust between firms, the range of communication means used expands, though interacting face-to-face remains the preferred mean when interdependent activities need to be coordinated (e.g. Mu, Peng and Love, 2008).

Spatial proximity is also essential to access external knowledge, though its relevance becomes less important once a collaborative relationship has been established. Yet, its role is more than contextual to being a pre-condition for face-to-face communication. For once, colocation favours becoming aware of what is taking place in the neighbourhood, through the higher chance of encountering key people or information and data accidentally, or being exposed to relevant local public knowledge and gossip, shared customers and suppliers, consultants, local institutions and organisations. On the other side, spatial proximity enables the creation of networks amongst people, which continue to exist even when individuals are no longer near to each other. For example, it has been shown that the number of joint patents between a scientist and his/her previous workplace can be as much as $50 \%$ higher when the inventor worked there than if s/he did not (Agrewal, Cockburn and McHale, 2006). Institutional programmes promoting the international mobility of researchers (e.g. the 'Erasmus' programme in the EU) are based on the same principle that a temporary stay in a foreign laboratory favours the professional development of young researchers as well as their future opportunities for international collaborations regardless of where they will be located (e.g. Ackers, 2005).

More controversial is the influence of the duration of interacting. Firms wanting to access external knowledge seem able to do so without having to establish a permanent functional unit or activity focused on this purpose. Research has shown that when agents do not face a time constraint for interacting, as in the case of permanent geographic co-location, the knowledge acquired by a firm through its network can remain within the supply chain and not spread to the neighbourhood (Gallie, 2009). At the same time, significant knowledge flows 
can result from very short encounters, like those taking place during trade fairs and conferences (e.g. Bathelt and Schuldt, 2008), and short academic visits (e.g. Hamermesh, 2006). A short initial interaction can develop into a long-lasting collaboration thanks to the communication 'pipelines' established during the first visit.

The insights of these two streams of work are relevant for selecting some of the explanatory variables for the empirical analysis and the reference groups when these are categorical. They are also useful to contextualise the use of a quasi-objective measure of knowledge production, which is constructed from the answers to a large survey of international business visitors.

\section{The airport survey and the measurement of knowledge}

The survey was carried out in November 2006 across four of Australia's international airports: Sydney, Melbourne, Brisbane and Adelaide. These account for over $80 \%$ of the volume of international travel from and to Australia. Travellers were approached at the boarding gates after immigration and passport controls by licensed surveyors. Respondents were initially asked whether they were travelling for work-related purposes. Only upon an affirmative response, the interview continued. Overall, 1,016 Australian residents and 966 foreign residents returning home were interviewed. Non-response was minimal (less than 5\% of those approached), and only one employee per organisation was interviewed.

Age, gender, occupation, and country of origin of the respondents were compared with a second random sample of departure and landing cards of business visitors during the same period, which was carried out by Australia's Department of Immigration and Citizenship (DIAC), and the population of business visitors in the same year. With the exception of an over-representation of travellers to and from New Zealand, the characteristics of the respondents of the airport survey resulted very similar to those of the people sampled by DIAC and the overall population (for details see Tani, 2010). The airport survey revealed that 
business visitors share similar personal and occupational characteristics. They are mostly males, aged between 35 and 44, professionals or managers employed by either a multinational company or a small-medium sized firm with less than 100 employees. The functional units most commonly engaged in business visits are production, strategy and training. Less relevant is the presence of those working in sales and marketing. Respondents are mostly specialist managers, IT professionals and scientists and engineers. There is also a significant number of health specialists working for government and NGOs, typically providing medical and other health relief to areas in less developed countries.

The airport survey shows that each type of employer uses international business visits to interact in each of the four major categories identified (Table 1): these are visits to other parts of the same organisation or affiliate, to parts of the same supply chain, to new customers and suppliers, and to conferences and trade fairs. Finding that each type of employer uses visits across these interaction types suggests that corporations, governments and NGOs are contemporaneously engaged in a variety of interactions with the external environment. As such, they face choices about which one to prioritise or be strategic about, if any, as each employer has have limited financial, time, and human resources.

The identification of 'knowledge' relies on the answer to an open-ended question about the counterfactual to what would occur to the respondent's employer if the visit did not take place. Respondents were not prompted in any way before formulating their answer; they were not told to give a single reason (though they were asked to highlight the most important consequence) or were allowed to give more than one; they were however invited to rank the most important reason if they gave more than one. Their answers could be classified in a handful of broad topics, as illustrated by the sample in Table 2. The author and two other researchers independently organised the responses into five mutually exclusive categories: (1) certain or potential financial losses; (2) separation from the industry's best practice and latest 
developments; (3) break-ups, or diminished strength, of an existing relationship with a customer or supplier; (4) other effects, such as legal liabilities stemming from neglecting a contractual responsibility; and (5) no major consequence. The frequency of these answers by type of interaction is reported in Table 3. The most common counterfactual is the fear or certainty of negative financial implications. These tend to include the loss of contracts, inability to beat competitors or to complete a contractual responsibility. The second most common counterfactual is the prospect of 'knowledge loss', seen as the wedge between a continually moving industry's best practice and the employer's competitive position. This motivation is particularly common for visits within the same organisation, and to conferences and trade fairs. The third but distant most common counterfactual is the possibility of negatively affecting an existing relationship. Not making the effort to carry out a visit is generally seen as a sign of no or diminished commitment, particularly in trips to and from Asia.

\section{The determinants of knowledge-related IBTs flows}

To analyse the determinants of firms' choice of interactions I apply a multinomial logit (MNL) to the interaction type. This approach is motivated by the fact that the interaction type represents a choice between a relatively small number of mutually exclusive alternatives with no particular order of preference of rank. The MNL model also applies to explanatory variables that are case-specific. In other words, their value does not change according to the alternative chosen as might be the case if the same individual were asked to state his or her preferences should s/he choose to interact in each of the four categories. The analysis uses visits within the same organisation as the reference group since this is the form of interaction most discussed by the literature on knowledge transfers (especially when within MNC) and constitute a natural reference group. 
Formally, the model estimated is:

$$
p\left(y_{i}=j\right)=\frac{\exp \left(X_{j i}^{\prime} \beta_{j}\right)}{1+\sum_{l=2}^{m} \exp \left(X_{l i}^{\prime} \beta_{l}\right)}
$$

while the reference outcome category is:

$$
p\left(y_{i}=1\right)=\frac{1}{1+\sum_{l=2}^{m} \exp \left(X_{l i}^{\prime} \beta_{l}\right)}
$$

where $i$ refers to the observation, $j$ is one of the $m$ outcomes, $\mathrm{X}$ is a set of case-specific regressors that include the features of the visit (number in a year and average duration), its destination and origin, and the demographic, educational, and occupational characteristics of the visitor, including the type of employer, industry, and functional unit. The subscript $m$ represents the three other interaction types. The full list of the covariates and their summary statistics are displayed in Table 4. Since all variables are categorical, the mean corresponds to the proportion of observations in the group described relative to the total, and the reference group for variables with multiple categories are highlighted in the description column.

In the empirical analysis I omit trips carried out for purposes classified as 'other'. These contain a heterogeneous group often related to training and briefings for self-employed or within larger organisations (e.g. interviews for promotion/relocation). Although it would be possible to reclassify these observations, their limited number is too small to obtain marginal effects when considered as a separate group.

The estimation is carried out through maximum likelihood methods, and all regressions are performed controlling for heteroskedasticity across sub-groups (robust estimation). The Independence of Irrelevant Alternatives assumption (IIA) is tested with a Hausman test between the unrestricted model containing all categories of the dependent variable and restricted models where these are alternatively excluded. A multinomial probit model is also 
estimated, which is not subject to the IIA assumptions. Since both approaches yield very similar marginal effects (available from the author), the discussion focuses on those obtained by MNL.

The top row if Table 5 shows the predicted probability of using business visits to interact. Business visits are most common to another part of the same organisation (predicted probability is $39.8 \%$ - not shown), followed by visits within the same supply chain $(30.2 \%)$, to new customers and suppliers (15.3\%) and to conferences and trade fairs (14.7\%). The main body of Table 5 reports the marginal effects of the estimates obtained by MNL. These measure the change in the probability of choosing an interaction type relative to the reference group when the explanatory variable is included (more precisely, when its value changes from zero to one.) An effect statistically different from zero at the $1 \%, 5 \%$ and $10 \%$ level of significance is highlighted with '***', '**', or '*', respectively.

The results show that there are substantial differences among interaction types depending on the frequency of the interaction, type of employer and functional unit involved, and the characteristics of the employees carrying them out.

Visits within the supply chain are more frequent and longer than those within the same organisation. When the frequency of visits doubles from 2-5 to over 10 each year the probability of visiting a company within the supply chain is about $10 \%$ higher than visiting a subsidiary. A similar marginal effect exists when the length of stay is extended from one to three weeks or more per visit. The probability of interacting within the supply chain rises by over $18 \%$ if the visit is carried out by a SME rather than a MNC or even a large domestic employer, indicating that the onus of interacting within a supply chain tends to fall on smaller partners. These visits are more likely to be carried out by functional units involved in production $(+6 \%)$, and significantly less by those in strategy $(-10 \%)$, than in training, coordination, and sales and marketing (the reference group). These trips are also far more 
likely to be carried out by visitors working in manufacturing companies (reference group) vis-à-vis those employed in mining (-9\%), utilities (-12\%), construction (-15\%), transport (9\%), finance (-10\%), and culture/recreation (-9\%). These results suggest that visits within the supply chain occur as a consequence of the outsourcing of production rather than in later stages of a firm's value added process (e.g. distribution). This is perhaps a consequence of the redistribution of manufacturing jobs towards lower labour-cost economies that has accompanied the globalisation of the world's economy (e.g. Krugman, 2007). This hypothesis is further substantiated by the fact that scientists are less likely to carry out this type of interactions than engineers and those graduated in other fields (include those without a degree) (-6\%), who might occupy less field-specific jobs. Australian residents are more likely to carry out these trips than foreign residents (+3\% though significant only at the $10 \%$ level), suggesting that Australia's small population and large geographic distance from other markets may give its resident firms extra incentives to seek interactions outside the national boundaries, obliging them to sustain the associated costs. In contrast, the probability of visiting part of the supply chain is not affected by the gender of the visitor $(-1.5 \%$ but statistically insignificantly different from zero), whether one owns the company one works for, and the formal educational level completed.

Interactions with new customers and suppliers are infrequent (-6\%) and shorter (+4\%) than visits to parts of the same organisation, against the prior that firms constantly try to establish new contacts. SME are more likely than any other type of firm to undertake this type of interaction (+8\%). Being a company owner rises the probability of making these visits vis-àvis being an employee $(+8 \%)$, as is working in sales and marketing relative to being employed in any other functional unit. This result identifies sales and marketing as the clear main purpose to carry out visits to potential customers and suppliers. The likelihood of this type of interaction is broadly identical across all sectors of the economy (though employment 
in the public sector lowers it by 6\%), and countries of origin or destination. This suggests that it is a common activity carried out by firms regardless of their sector of activity and host country. However, it is significantly higher for foreign residents, suggesting a stronger effort on their part to penetrate the Australian market, possibly due to the high income per capita of its inhabitants, relative to the flow in the opposite direction. The use of visits to interact with new clients is affected by gender (being a female lowers the probability of these visits by 7\%) and the level of formal education (-4\% for non-university graduates). No effect instead arises from the field of education, as scientists, engineers, and those graduating from other fields have an almost identical effect on the probability of interacting this way.

Visits to conferences are occasional and relatively short in duration. The marginal effects of an annual trip relative to the reference group is +.07 , while it is negative for trips of $6-10$ ($.09)$ or 10 or more annual trips (-.12). The marginal effects of stays of two weeks rather than one are also negative (-.08), and so are those for even longer stays (-.19). By far, the most common employers using business trips to attend conferences and trade fairs are government, NGOs, and universities (+21\% relative to any other type of firm), in line with the hypothesis that these events have a clear positive bias towards sharing information, a public good, vis-àvis rival and excludable information, porducts and services. Yet, those employed in a training function are as likely as those in strategy and sales and marketing to attend conferences and trade fairs suggesting that knowledge access is similarly sought among the various functional units. In contrast, these events are less likely to be attended by those working in production (4\%) and coordination (-6\%). The likelihood of interacting through conferences and trade fairs is higher if one works in agriculture $(+10 \%)$ than in manufacturing, and for those working in construction $(+17 \%)$, retail trade $(+14 \%)$, and communication $(+9 \%)$. It is also substantially higher for women (+5\%), scientists $(+7 \%)$, and those with a PhD (+7\%). Being the owner of 
a firm does not affect the likelihood of interacting through these activities, nor does the country of residence.

Overall, these results support viewing visits as the consequence of strategic choices made by firms about how to interact with the external environment. The question arising is whether these interactions relate to accessing external knowledge, if at all. The answer can be obtained by estimating the probability of gaining knowledge using the counterfactual from the airport survey. In particular, a dichotomous variable can be constructed, equalling one if non-travelling leads to a knowledge loss (proxying for access to external knowledge) and zero otherwise.

Estimation of this equation is problematic, as it does not take into account the likely simultaneity between whether or not new knowledge is gained and the choice of interaction type. Firms might in fact be more freely share crucial information in visits to a subsidiary than in meeting a new potential customer for a number of reasons: some may be captured by available variables (e.g. firm size), and can be controlled for; others may be unobservable and cause non-random heterogeneity within the interaction categories. This heterogeneity is a source of bias if not controlled for, as it does not account for the higher, non-random likelihood that non-travelling leads to a knowledge loss in the case of visits to parts of the same organisation vis-à-vis those to new clients and suppliers. However, this issue can be overcome by jointly estimating the probabilities of gaining knowledge and the chosen type of interaction to access it. The bivariate probit model provides a natural approach to estimate the system of two simultaneous equations, as it allows the covariance between the error terms of the two equations to differ from zero. Technically, the estimation follows that of models with unobserved limited dependent variables, as defined by:

$$
\begin{aligned}
& y_{1}^{*}=X_{1}^{\prime} \beta_{1}+\varepsilon_{1} \\
& y_{2}^{*}=X_{2}^{\prime} \beta_{2}+\varepsilon_{2}
\end{aligned}
$$


where $y_{1}^{*}$ and $y_{2}^{*}$ are unobserved binary outcomes but where the errors $\varepsilon_{1}$ and $\varepsilon_{2}$ (jointly normally distributed with means of zero and variances of one) have a non-zero correlation $\rho$ (rho). The two observed outcomes are instead:

$y_{1}=\left\{\frac{1 i f y_{1}^{*}>0}{0 i f y_{1} \leq 0}\right\}$ which represents the relative probability of a knowledge exchange (a binary variable); and

$y_{2}=\left\{\frac{1 i f y_{2}^{*}>0}{0 i f y_{2}^{*} \leq 0}\right\}$ which represents the relative probability of choosing one interaction over another.

If rho is zero then the system collapses and the two probabilities can be estimated independently of each other. Since the dependent variable of the second equation contains four categories but the model can be estimated only if this is binary, three separate regressions are estimated. In each, the three binary dependent variables share one category (the probability of carrying out a visit within the same organisation) but its other value represents respectively a visit to:

1. parts of the supply chain (first regression);

2. new clients and suppliers (second regression);

3. conferences and trade fairs (third regression).

The use of the same reference group allows one to better compare the marginal effects of the three sets of results. The estimates are reported in Table 6 while Table 7 displays the associated conditional marginal effects, by interaction type.

For each bivariate probit, the test of independence between the two probabilities is rejected, suggesting that the likelihood of accessing knowledge is not independent of the chosen type of interaction. This result supports using the joint estimation approach undertaken. In particular, with reference to visits to companies within the supply chain and to new clients 
and suppliers, the selection is negative, implying that these visits tend to involve less access to knowledge than visits carried out within the same organisation (rho: -.21 and -.268, respectively. Both are highly statistically significantly different from zero). In contrast, the selection for attending conferences and trade fairs is positive and highly statistically significant (rho: .21), implying that these visits are far more likely to lead to knowledge gains than those within the same organisation. The results show that even conditioning on the type of interaction there is a significant use of international business visits to access external knowledge among all types of employers.

The conditional predicted probability of accessing knowledge within the supply chain is $17.6 \%$. In other words, there is a $17.6 \%$ chance that knowledge is gained, or, alternatively, that non-travelling mainly creates a knowledge loss, when firms use international business visits for this type of interaction relative to visits within the same organisation. The conditional predicted probability for visiting new clients and suppliers is $14.3 \%$. This is the lowest of the four estimates, but it is not insignificant as it implies that one in six visitors meeting a new client or supplier still does so to access external knowledge. In contrast, the conditional predicted probability for visits to conferences and trade fairs is $47.9 \%$, the highest among those estimated. Not attending the conference or trade fair results in a knowledge loss for almost half of the sample surveyed. This result makes participation to conferences and trade fairs more similar to an investment in accessing external knowledge rather than expenditures or rewards.

The conditional predicted probabilities are also affected by the frequency and duration of the interaction, the type of employer and functional unit involved, and the characteristics of visiting employee. In the case of visits within the supply chain, higher frequencies have a negative marginal effect. Making more visits per annum reduces the likelihood of gaining knowledge by about $7 \%$ (from $17.6 \%$ to $10.6 \%$ ). A similar effect is associated to even more 
frequent visits. No significant marginal effect is associated with the variables measuring the duration of each interaction. Visits carried out by government, NGOs and the tertiary sector have a positive marginal effect (+.13). This is perhaps not surprising as these trips include visits to international affiliates, like a corresponding foreign university or foreign aid partner, and are carried out by employees working in training functional units. Being a scientist has also a positive marginal effect (+.06), though it has statistical significance only at the $10 \%$ significance level. Virtually every sector aside from manufacturing and construction is associated with negative marginal effects, with substantial reductions in the predicted probability of knowledge gains. The most significant are agriculture (-.15), wholesale (-.15) and retail trade (-.07). In contrast, the marginal effects associated with gender, age, and education level are statistically insignificantly different from zero.

The marginal effects obtained for visits to new clients and suppliers are also negative if the annual visits are more frequent than the reference group (2-5), and if they extend over long periods of time (-.07 if the visits lasts $21+$ days). Similar to visits within the supply chain, there is a positive marginal effect if the visit is carried out by government, NGOs or universities (+.129), and if visitors work in a training functional unit (+.159). Being a scientist also slightly increases the likelihood of accessing knowledge (+.058). Working in manufacturing, mining, construction, accommodation and finance have similar marginal effects, perhaps as these sectors are the most commonly represented in trips aimed at developing new relationships. In contrast, negative marginal effects are associated with being employed in agriculture (-.146), utilities (-.106), retail trade (-.078), transport (-.075) and culture/recreation (-.108). The conditional predicted probability of visits to new customers or suppliers is not affected by the visitors' country of residence, travel patterns, and ownership of the firm, as the corresponding marginal effects are statistically insignificantly different from zero. 
As for the previous cases, the conditional predicted probability for participating to conferences and trade fairs is negatively affected by a high frequency of interaction (-.094 for $10+$ visits per annum). Interestingly, too few interactions have also a negative marginal effect (-.065), suggesting the presence of a U-inverted relationship between interacting and gaining knowledge. No effect instead is related to the length of stay, though the negative coefficient of the relevant marginal effect becomes progressively larger and statistically significant if this grows from one week (the reference group) to two (-.025) and three or more (-.033). Working for government, NGOs and universities raises the probability of a knowledge gain (+.11), but the result is significant only at the $10 \%$ significance level. On a more stringent significant cut-off, the marginal effect across employer categories is not statistically significant, implying that the likelihood of accessing knowledge in conferences or trade fairs applies regardless of the type of organisation one works for.

Positive marginal effects are associated with working in strategy $(+.186)$, production $(+.108)$, coordination (+.138), and training (+.235). These results further support that conference and trade fairs are opportunities for knowledge exchanges rather than for sales and marketing. Negative marginal effects are associated with finance (-.157) and cultural and recreational services (-.234). This result might be related to the fact that these two sectors are historically characterised by slow productivity growth. For these, conferences and trade fairs might not provide as many opportunities for gaining new knowledge relative to marketing a product or service. As for other types of interaction, the marginal effect associated with the country of residence and travel patterns are statistically no different from zero, suggesting the absence of a geographic bias. Marginal effects insignificantly different from zero are also obtained for the level and field of education, and gender, implying that the likelihood of gaining knowledge in this type of interaction is not specific to discipline, sex or formal qualifications. In contrast, negative significant effects arise for the age groups above 35-44, suggesting that 
conferences and trade fairs provide the strongest opportunities to gain knowledge for those of younger ages.

As knowledge gains exist in each type of interaction carried out through international business visits, albeit with different probabilities, all employers have a strong scope to be strategic in choosing the type of interaction as well as allocating well thought budgets and personnel to carry them out.

\section{$5 \quad$ Implications for policy and conclusions}

These results show how firms and organisations use international business visits to interact with each other and that access to knowledge motivates their existence regardless of the type of interaction. Macroeconomic studies of international business visits suggest the existence of a positive correlation between visits and productivity/growth. But it is the study of several cases in depth that can reveal how organisations make use of interactions to keep abreast, or push forward, the knowledge frontier. Mobility aimed at interacting, for example through international business visits, can add to an organisation's efficient use of human resources. Unfortunately, qualitative data suggest otherwise. As an example, it is found that business visitors to be managed locally by line managers rather than 'holistically' despite their knowledge and activities are valuable to the whole organisation (e.g. Welch, Welch, and Worm, 2007). Similarly, there are no additional incentives beyond full tax deduction to participate in conferences and trade fairs though organisations and governments generally recognise that a 'knowledgeable' workforce is highly desirable. Cutting travelling budgets reduces financial expenditures. But it also reduces opportunities to interact and, with it, the access to external knowledge. 


\section{References}

Ackers, L. (2005). "Moving People and Knowledge: Scientific Mobility in the European Union”, International Migration, 43(5), 99-131.

Ambos, T., Ambos, B. and B. Schlegelmilch (2006). "Learning from foreign subsidiaries: an empirical investigation of headquarters' benefits from reverse knowledge transfers, International Business Review, 15, 294-312.

Agarwal, A., Cockburn, I. and J. McHale (2006). “Gone But Not Forgotten: Labor Flows, Knowledge Spillovers and Enduring Social Capital”, Journal of Economic Geography, 6(5), 571-591.

Amin, A. and Cohendet, P. (2004). Architectures of Knowledge, Oxford: Oxford University Press.

Andersen, T.B. and Dalgaard, C.J., 2007, Cross-border Flows of People, Technology Diffusion and Aggregate Productivity, University of Copenhagen, Working Paper: http://www.econ.ku.dk/dalgaard/research.htm

Anderson, E., Tang, P. and A. Wood (2006). "Globalization, co-operation costs, and wage inequalities", Oxford Economic Papers, 58(4), 569-595.

Arrow, K. (1962). "The economic implications of learning by doing”, Review of Economic Studies 29(3), 155-173.

Australian Bureau of Statistics (ABS) (various years). 'Overseas Arrivals and Departures”, publication no. 3401.0. Canberra: ABS

Bathelt, H. and N.A. Schuldt (2008). "Between Luminaires and Meat Grinders: International Trade Fairs as Temporary Clusters”, Regional Studies, 42, 853-868.

Bathelt, H., Malmerg, A., Maskell, P. (2004), 'Clusters and knowledge: local buzz, global pipelines and the process of knowledge creation', Progress in Human Geography, 28(1), 31-56.

Burt, R.S. (1997). “A note on social capital and network content”, Social Networks, 19, 355-373.

Button, K.J. and H. Vega (2008). "The effects of air transportation on the movement of labor”, GeoJournal, 71(1), 67-81.

Cohen, W. and Levinthal, D. (1989). "Innovation and Learning: the Two Faces of R\&D”, Economic Journal, 99(397), 569-596.

Collings, D.G. Scullion, H. and Morley, M.J. (2007) "Changing Patterns of Global Staffing in the Multinational Enterprise: Challenges to the Conventional Expatriate Assignment and Emerging Alternatives”, Journal of World Business, 42(2), 198-213. 
Dahl, M., and C. Pedersen (2004), "Knowledge flows through informal contacts in industrial clusters: myth or reality?", Research Policy, 33(10), 1673-86.

Dosi, G. et al. (eds) (1988). Technical Change and Economic Theory, Maastricht Economic Research Institute on Innovation and Technology (MERIT), International Federation of Institutes for Advanced Study (IFIAS) Research Series, no. 6. London and New York: Pinter.

Dowrick, S. and M. Rogers (1995). Economic approaches to innovation. Aldershot, U.K.: E. Elgar.

Dowrick, S. and Tani, M. (2008). 'International business visits and the technology frontier', IZA discussion paper no. 3417, Bonn: IZA.

Franco, A.M. and D. Filson (2000). 'Knowledge diffusion through employee mobility', Staff Report 272, Federal Reserve Bank of Minneapolis.

Gallie, E.P. (2009). "Is Geographical Proximity Necessary for Knowledge Spillovers within a Cooperative Technological Network? The Case of the French Biotechnology Sector", Regional Studies, 43(1), 33-42.

Grant, R.M. (1996). “Toward a Knowledge-Based Theory of the Firm,” Strategic Management Journal, 17, Winter special issue, 109-122.

Gupta, A.K. and Govindarajan, V. (2000). "Knowledge Flows within the Multinational Corporation”, Strategic Management Journal, 21, 473-496.

Hamermesh, D. (2006). "The value of peripatetic economists: a Sesqui-difference evaluation of Bob Gregory”, Economic Record, 82(257), 138-149.

Hansen, M.T. (1999). "The search-transfer problem: The role of weak ties in sharing knowledge across organization subunits”, Administrative Science Quarterly, 44(1), 82-111.

Kogut, B., and Zander, U. (1992). "Knowledge of the Firm, Combinative Capabilities, and the Replication of Technology” Organization Science, 3(3), 383-397.

Kraatz, M.S. (1998). "Learning by Association? Interorganizational Networks and Adaptation to Environmental Change”, Academy of Management Journal, 41(6), 621-643.

Krugman, P. (2007). “Does outsourcing change everything?”, Fifth Luca d'Agliano Lecture in Development Economics, Fondazione Luigi Einaudi, Turin, Italy, 11 June. http://www.dagliano.unimi.it/media/krugman_lecture_torino.pdf accessed on 21st July 2009.

International Air Transport Association - IATA (2007). Fare Tracker. Accessed $2^{\text {nd }}$ May, 2009 http://www.iata.org/ps/publications/fare-tracker.htm

International Air Travel Survey (IATS) (1988). The European Frequent Business Traveller. Henley on Thames: European Data and Research Limited. 
Maskell, P., Bathelt H. and A. Malmerg (2006). Building Global Knowledge Pipelines: The Role of Temporary Clusters, European Planning Studies, 14, 997-1013.

McFadden, D. (1973). “Conditional logit analysis of qualitative choice behaviour”. In P.Zerembka, Frontiers in Econometrics, Academic Press.

Minbaeva, D. and S. Michailova (2004). "Knowledge transfer and expatriation in multinational corporations: The role of disseminative capacity", Employee Relations, 26(6), 663-679.

Mu, J., Peng, G. and E. Love (2008). "Interfirm networks, social capital, and knowledge flow”, Journal of Knowledge Management, 12(4), 86-100.

Nelson, R. and S. Winter (1982). An Evolutionary Theory of Economic Change, Belknap Press.

National Business Travel Association (2009). A Global Analysis of Business Travel Activity.

Nonaka, I., Konno, N. (1998). "The concept of 'ba': building a foundation for knowledge creation", California Management Review, 40(3), 40-54.

Nonaka, I. and Takeuchi (1995). The Knowledge-creating company. New York: Oxford University Press.

Noordherhaven, N. and A.W. Harzing (2008). 'Knowledge sharing and social interaction within MNCS', forthcoming in the Journal of International Business Studies.

Office of National Statistics (ONS) (2001). 'Travel trends - A report on the 2000 International Passenger Survey’. London: The Stationery Office.

Ouaked, S. (2002). “Transatlantic Workshop on High Skilled Migration”, International Migration, 40(4), 153-64.

Park, J.S. (2004). “International Student Flows and R\&D Spillovers”, Economics Letters, 82(3), 315-320.

Polanyi, M. (1966). The Tacit Dimension, Gloucester: Peter Smith

Portes, Alejandro. 1998. "Social capital: its origins and applications in modern sociology", Annual Review of Sociology, 24, 1-25.

Riusala, K. and Suutari, V. (2004). 'Expatriate as Knowledge Transferor: Impediments to International Knowledge Transfers through Expatriates’. Proceedings of the EURAM04 Conference (http://www.st-andrews.ac.uk/ euram04). Accessed $21^{\text {st }}$ July 2009.

Rogers, M. (2004). “Networks, firm size, and innovation”, Small Business Economics 22, 141-153.

Rogers, M. (1995). International Knowledge Spill-Overs: A Cross-Country Study. In 
Steve Dowrick (ed), Economic Approaches to Innovation. Aldershot, UK and Brookfield, US: Edward Elgar Publications.

Salt, J. (1992). "Migration Processes among the Highly Skilled in Europe". International Migration Review, 26(2), 484-505.

Singh, J. (2005), “Collaborative Networks as Determinants of Knowledge Diffusion Patterns”, Management Science, 51, 756-770.

Storper, M. and A.J. Venables (2004). "Buzz: face-to-face contact and the urban economy", Journal of Economic Geography, 4(4), 351-370.

Tani, M. (2010). “International Labour Visits and Knowledge Transfers”, Asian and Pacific Migration Journal, 19(1), 117-139.

Tani, M. (2008). "Short-term skilled labour movements and economic growth", International Migration, 46(3), 161-187.

Welch, D., Welch, L. and V. Worm (2007). "The international business traveller: a neglected but strategic human resource”, International Journal of Human Resource Management 18(2), 173-183.

Wood, A. (2001). "Globalisation and Wage Inequalities: A Synthesis of Three Theories”, Weltwirtschaflisches Archiv, 138(1), 54-82.

Zellner, C. (2003). “The economic effects of basic research: Evidence for embodied knowledge transfer via scientists' migration”, Research Policy, 32, 1881-1895. 


\section{Appendix}

\section{TABLE 1 CONSEQUENCE OF Not TRAVELLING BY TYPE OF INTERACTION}

\begin{tabular}{|c|c|c|c|c|c|c|}
\hline \multirow[b]{2}{*}{ Employer $\downarrow$} & \multicolumn{6}{|c|}{ Types of interaction } \\
\hline & $\begin{array}{c}\text { Pooled } \\
\text { data }\end{array}$ & $\begin{array}{l}\text { Within } \\
\text { same firm }\end{array}$ & $\begin{array}{l}\text { Within } S- \\
\text { chain }\end{array}$ & $1^{\text {st }}$ visit & $\begin{array}{l}\text { Confer., } \\
\text { trade fair }\end{array}$ & Other \\
\hline MNC & $37 \%$ & $55 \%$ & $33 \%$ & $29 \%$ & $21 \%$ & $16 \%$ \\
\hline $\begin{array}{l}\text { Large domestic } \\
\text { employer }\end{array}$ & $11 \%$ & $12 \%$ & $12 \%$ & $12 \%$ & $9 \%$ & $10 \%$ \\
\hline SME & $32 \%$ & $21 \%$ & $47 \%$ & $49 \%$ & $20 \%$ & $30 \%$ \\
\hline $\begin{array}{l}\text { Government, NGO, } \\
\text { university }\end{array}$ & $19 \%$ & $12 \%$ & $7 \%$ & $10 \%$ & $50 \%$ & $45 \%$ \\
\hline Total & $\begin{array}{r}\mathbf{1 , 9 8 2} \\
100.0 \%\end{array}$ & $\begin{array}{r}\mathbf{6 8 5} \\
100.0 \%\end{array}$ & $\begin{array}{r}535 \\
100.0 \%\end{array}$ & $\begin{array}{r}\mathbf{2 9 0} \\
100.0 \%\end{array}$ & $\begin{array}{r}389 \\
100.0 \%\end{array}$ & $\begin{array}{r}\mathbf{8 3} \\
100.0 \%\end{array}$ \\
\hline
\end{tabular}

TABle 2 ORganising COUNTERFACTUALS: 'RAW' EXAMPLES

\begin{tabular}{|c|c|c|}
\hline Occupation & Consequence if visit does not take place (recorded answer) & $\begin{array}{l}\text { Category } \\
\text { assigned }\end{array}$ \\
\hline $\begin{array}{l}\text { Office Manager } \\
\text { and Company } \\
\text { Director }\end{array}$ & I wouldn't be able to keep pace with the head office in US. & Knowledge loss \\
\hline $\begin{array}{l}\text { Marketing } \\
\text { Director- } \\
\text { consumable } \\
\text { goods. }\end{array}$ & $\begin{array}{l}\text { I wouldn't be informed about the new things my company } \\
\text { would like to implement next year. My HQ wouldn't be } \\
\text { informed about what is going on here. }\end{array}$ & Knowledge loss \\
\hline $\begin{array}{l}\text { Package } \\
\text { Engineer. }\end{array}$ & $\begin{array}{l}\text { Latest trends, in the technology sector we might miss out on } \\
\text { common knowledge. }\end{array}$ & Knowledge loss \\
\hline Sales Manager. & Wouldn't develop new ideas, less competitive. & Knowledge loss \\
\hline $\begin{array}{l}\text { Company } \\
\text { Director } \\
\text { Commercial } \\
\text { Laundry.. }\end{array}$ & Need to check out latest equipment, keeping up to date. & Knowledge loss \\
\hline $\begin{array}{l}\text { Structural } \\
\text { engineer. }\end{array}$ & $\begin{array}{l}\text { Would not be able to design and learn about new techniques, } \\
\text { keeps clients happy. }\end{array}$ & Knowledge loss \\
\hline $\begin{array}{l}\text { Manufacturer of } \\
\text { woollen } \\
\text { products. }\end{array}$ & $\begin{array}{l}\text { Would not be in touch with market, would not have latest } \\
\text { designs. }\end{array}$ & Knowledge loss \\
\hline $\begin{array}{l}\text { IT Solution } \\
\text { Architect }\end{array}$ & $\begin{array}{l}\text { The client would not have received proper training in software } \\
\text {. }\end{array}$ & Knowledge loss \\
\hline $\begin{array}{l}\text { General } \\
\text { Manager }\end{array}$ & $\begin{array}{l}\text { No new business if we did not go overseas to keep updated } \\
\text { with new techniques and skills for the car industry. }\end{array}$ & Knowledge loss \\
\hline $\begin{array}{l}\text { Director of } \\
\text { Company }\end{array}$ & $\begin{array}{l}\text { Will lose the opportunities to learn new strategies for } \\
\text { International business (import and export). }\end{array}$ & Knowledge loss \\
\hline Paediatrician & Decrease efficiency/ We're exchanging ideas with hospitals. & Knowledge loss \\
\hline $\begin{array}{l}\text { Miscellaneous } \\
\text { Health } \\
\text { Professionals }\end{array}$ & $\begin{array}{l}\text { Diminishing of education standards in transplant immunology } \\
\text { ie of knowledge sharing in this field. }\end{array}$ & Knowledge loss \\
\hline $\begin{array}{l}\text { Artists and } \\
\text { Related } \\
\text { Professionals }\end{array}$ & $\begin{array}{l}\text { Wouldn't see what my colleagues are doing in the world of } \\
\text { natural dyes and maintaining an association with one's own } \\
\text { intellectual property which is vital. }\end{array}$ & Knowledge loss \\
\hline
\end{tabular}




\begin{tabular}{|l|l|l|}
\hline Travel Agent & $\begin{array}{l}\text { If we don't travel we're not educated to pass on our knowledge } \\
\text { to our clients-can't learn it from a book. }\end{array}$ & Knowledge loss \\
\hline $\begin{array}{l}\text { Teacher, } \\
\text { Professor }\end{array}$ & $\begin{array}{l}\text { Not keeping up with development of science and } \\
\text { technology/not up to date. }\end{array}$ & Knowledge loss \\
\hline
\end{tabular}

\begin{tabular}{|l|l|l|}
\hline $\begin{array}{l}\text { Accountants, } \\
\text { Auditors and } \\
\text { Corporate } \\
\text { Treasurers }\end{array}$ & Particular client I am visiting wouldn't use us on this occasion. & Relationship loss \\
\hline $\begin{array}{l}\text { Account/Sales } \\
\text { Director }\end{array}$ & $\begin{array}{l}\text { No personal contact, no close relationship with clients which } \\
\text { eventually means less businesr }\end{array}$ & Relationship loss \\
\hline $\begin{array}{l}\text { Engineer - } \\
\text { Manufacturing } \\
\text { Consultant }\end{array}$ & $\begin{array}{l}\text { Business would take longer to start. We are starting a business } \\
\text { in China. }\end{array}$ & Relationship loss \\
\hline $\begin{array}{l}\text { Company } \\
\text { Director }\end{array}$ & $\begin{array}{l}\text { long term relationships with senior Management would be } \\
\text { weaker. }\end{array}$ & Relationship loss \\
\hline IT Manager & Degradation of key client relationship on large contract. & Relationship loss \\
\hline $\begin{array}{l}\text { Earth moving/ } \\
\text { tech mechanic. }\end{array}$ & $\begin{array}{l}\text { Would lose reputation as good provider of customer service \& } \\
\text { consequently may lose business. }\end{array}$ & Relationship loss \\
\hline $\begin{array}{l}\text { General } \\
\text { Manager of } \\
\text { wholesale tool } \\
\text { company }\end{array}$ & $\begin{array}{l}\text { We would lose the agency if we didn't go this year. We are } \\
\text { exclusive agents for their tools. }\end{array}$ & Relationship loss \\
\hline $\begin{array}{l}\text { Combustion } \\
\text { Service } \\
\text { Engineer }\end{array}$ & Bad PR, bad reputation, wouldn't gain as much business. & Relationship loss \\
\hline $\begin{array}{l}\text { IT consultant, } \\
\text { software } \\
\text { function } \\
\text { application. }\end{array}$ & $\begin{array}{l}\text { More difficult to communicate due to our differences, } \\
\text { demoralization in relationship. }\end{array}$ & Relationship loss \\
\hline $\begin{array}{l}\text { Giftware buyer- } \\
\text { Manager }\end{array}$ & $\begin{array}{l}\text { I wouldn't have a customer left/ I need to make regular visits to } \\
\text { promote product }\end{array}$ & Relationship loss \\
\hline $\begin{array}{l}\text { Manager of a } \\
\text { software } \\
\text { co. }\end{array}$ & $\begin{array}{l}\text { The reason we are making this trip is to keep business by } \\
\text { establishing a personal relationship. We have a brand new } \\
\text { managing director \& wish to meet him personally. All the } \\
\text { follow-up will be done over the internet. You can't get the same } \\
\text { trust without a face to face meeting. }\end{array}$ & Relationship loss \\
\hline
\end{tabular}

\begin{tabular}{|l|l|l|}
\hline Vet Surgeon & $\begin{array}{l}\text { Lose business. There are a lot of horses travelling between } \\
\text { Australia and Hong Kong with Australian raised horses looked } \\
\text { after by Australian vets. }\end{array}$ & Financial loss \\
\hline $\begin{array}{l}\text { General } \\
\text { Manager } \\
\text { Medical } \\
\text { Equipment }\end{array}$ & $\begin{array}{l}\text { Lose money. We have competition and we must keep on with } \\
\text { the right decisions. As CEO/owner I have to be there. }\end{array}$ & Financial loss \\
\hline $\begin{array}{l}\text { Accountant } \\
\text { Retail }\end{array}$ & Lack of co-ordination effects/reduced profits. \\
\hline $\begin{array}{l}\text { Infrastructure } \\
\text { Manager/IT }\end{array}$ & Loss of business due to inability to bring new country on-line. & Financial loss \\
\hline Master mariner. & They would get someone else in. & Financial loss \\
\hline $\begin{array}{l}\text { Sales } \\
\text { Marketing. } \\
\text { Marine Industry }\end{array}$ & Lack of productivity if did not present new projects. & Financial loss \\
\hline $\begin{array}{l}\text { Electrical and } \\
\text { Electronics } \\
\text { Tradesperson }\end{array}$ & $\begin{array}{l}\text { Failure to get ongoing work from customers (if do not update } \\
\text { now on this trip). }\end{array}$ & Financial loss \\
\hline $\begin{array}{l}\text { National Sales } \\
\text { \& Marketing }\end{array}$ & Reduced business and revenue and lack of company growth. & Financial loss \\
\hline
\end{tabular}




\begin{tabular}{|l|l|l|}
\hline $\begin{array}{l}\text { Manager of } \\
\text { NZ }\end{array}$ & & \\
\hline $\begin{array}{l}\text { Photo Digital } \\
\text { Production } \\
\text { Processor. }\end{array}$ & Lose a client at least. & Financial loss \\
\hline $\begin{array}{l}\text { Technical } \\
\text { Trainer - } \\
\text { Telecoms co }\end{array}$ & $\begin{array}{l}\text { Projects would get delayed. Lots of the customers would be } \\
\text { looking for compensation as a result. }\end{array}$ & Financial loss \\
\hline $\begin{array}{l}\text { Race Horse } \\
\text { Trainer. }\end{array}$ & It would cost me a small percentage of business. & \\
\hline $\begin{array}{l}\text { Import/Export } \\
\text { Director (self } \\
\text { employed). }\end{array}$ & Sales would drop & Financial loss \\
\hline $\begin{array}{l}\text { Antique Dealer } \\
\text { self employed) }\end{array}$ & No stock, go broke. & Financial loss \\
\hline $\begin{array}{l}\text { Managing } \\
\text { director- } \\
\text { Advertising } \\
\text { Agency }\end{array}$ & $\begin{array}{l}\text { Less profitable - the trip has the potential to substantially } \\
\text { increase our turnover. }\end{array}$ & Financial loss \\
\hline $\begin{array}{l}\text { Sales \& } \\
\text { marketing- } \\
\text { technical IT } \\
\text { sales. }\end{array}$ & It would result in less market exposure \& declining customer & Financial loss \\
\hline IT Consultant & We would lose opportunity to market our company's services. & Financial loss \\
\hline $\begin{array}{l}\text { General } \\
\text { Manager for } \\
\text { airliner for NZ } \\
\text { \& Sth West } \\
\text { Pacific Region. }\end{array}$ & We would be unable to generate enough revenue for this region. & Financial loss \\
\hline
\end{tabular}

TABle 3 CONSEquence OF Not TraVelling BY TyPE OF INTERACTION

\begin{tabular}{lr|rrrrr}
\hline $\begin{array}{l}\text { Consequence of } \\
\text { not travelling } \downarrow\end{array}$ & $\begin{array}{c}\text { Pooled } \\
\text { data }\end{array}$ & $\begin{array}{c}\text { Within } \\
\text { same firm }\end{array}$ & $\begin{array}{c}\text { Types of interaction } \\
\text { Chain }\end{array}$ & $\mathbf{1}^{\text {st }}$ visit & Confer., & Other \\
trade fair & \\
\hline Financial loss & $43.9 \%$ & $36.1 \%$ & $62.1 \%$ & $66.6 \%$ & $19.8 \%$ & $25.3 \%$ \\
Miss on best practice & $29.6 \%$ & $30.5 \%$ & $18.3 \%$ & $15.2 \%$ & $53.0 \%$ & $36.1 \%$ \\
Nothing & $12.4 \%$ & $16.2 \%$ & $5.4 \%$ & $9.3 \%$ & $15.4 \%$ & $22.9 \%$ \\
Affect relationship & $10.4 \%$ & $11.4 \%$ & $12.7 \%$ & $7.6 \%$ & $8.5 \%$ & $7.2 \%$ \\
Other & $3.6 \%$ & $5.8 \%$ & $1.5 \%$ & $1.4 \%$ & $3.3 \%$ & $8.4 \%$ \\
\hline Total & $\mathbf{1 , 9 8 2}$ & $\mathbf{6 8 5}$ & $\mathbf{5 3 5}$ & $\mathbf{2 9 0}$ & $\mathbf{3 8 9}$ & $\mathbf{8 3}$ \\
& $100.0 \%$ & $100.0 \%$ & $100.0 \%$ & $100.0 \%$ & $100.0 \%$ & $100.0 \%$ \\
\hline
\end{tabular}


TABle 4 Summary STATISTICS

\begin{tabular}{|c|c|c|c|}
\hline Code & Mean & Std Dev & Description \\
\hline EFFECT_K & 293 & 455 & Dependent variable 1: No travel = no knowledge \\
\hline WITHIN & .795 & 404 & Dependent variable selection: 0 = go to conference \\
\hline EMP_1 & 181 & 385 & Employed by government, NGO, university \\
\hline EMP_2 & .371 & 483 & Employed by MNC (reference group) \\
\hline EMP_3 & .115 & .319 & Employed by large domestic firm \\
\hline EMP_4 & 324 & 468 & Employed by SME \\
\hline FNC_1 & 237 & 426 & Work in strategy department, CEO, owner \\
\hline FNC_2 & .220 & 414 & Work in production \\
\hline FNC_3 & 204 & 403 & Work in sales and marketing (reference) \\
\hline FNC_4 & 105 & .306 & Work in coordination (admin, HR, finance) \\
\hline FNC_5 & 138 & .345 & Work in training \\
\hline FNC_6 & .089 & 286 & Work in other departments \\
\hline NR_TRIPS1 & 127 & 333 & Travel internationally once a year \\
\hline NR_TRIPS2 & 426 & 495 & Travel internationally 2-5 times a year(refer) \\
\hline NR_TRIPS3 & 166 & 372 & Travel internationally 6-10 times a year \\
\hline NR_TRIPS4 & 283 & 451 & Travel internationally more than 10 times a year \\
\hline LENGTH_1 & 366 & 482 & Average stay per trip one day \\
\hline LENGTH_2 & .365 & 481 & Average stay per trip 2-5 days (reference) \\
\hline LENGTH_3 & 161 & 367 & Average stay per trip 6-10 days \\
\hline LENGTH_4 & 100 & 300 & Average stay per trip $11+$ days \\
\hline ONGOING & 200 & 400 & Trip is part of series \\
\hline GENDER & 126 & 333 & Female \\
\hline EDU_1 & 199 & 399 & Has high school degree of less \\
\hline EDU_2 & .435 & 496 & Has university degree (reference) \\
\hline EDU_3 & 255 & 436 & Has Masters’ degree \\
\hline EDU_4 & 109 & 312 & Has $\mathrm{PhD}$ \\
\hline AGE_1 & 199 & 400 & Age $<35$ \\
\hline AGE_2 & 324 & 468 & Age 35-44 (reference) \\
\hline AGE_3 & .304 & 460 & Age 45-54 \\
\hline AGE_4 & 170 & 376 & Age 55+ \\
\hline DEST_1 & .099 & 298 & Proportion of travellers to/from rest of world \\
\hline DEST_2 & .306 & 299 & Proportion of travellers to/from Asia \\
\hline DEST_3 & 195 & 397 & Proportion of travellers to/from Europe/North America \\
\hline DEST_10 & .394 & 489 & Proportion of travellers to/from New Zealand (refer) \\
\hline NO_S\&E & .501 & .500 & Degree other than science or engineering (refer) \\
\hline SCIENTIST & .213 & .410 & Scientist \\
\hline ENGINEER & .287 & 452 & Engineer \\
\hline RESIDENCE & .487 & .500 & Resident outside Australia \\
\hline D_PUBL & .235 & .424 & Work for the public sector \\
\hline $\mathbf{N}$ & 1,899 & & \\
\hline
\end{tabular}


Table 5 Marginal EfFects of Multinomial Logit

\begin{tabular}{|c|c|c|c|c|c|c|c|c|c|}
\hline \multirow[b]{2}{*}{ Variable } & \multicolumn{3}{|c|}{ Within S-chain } & \multicolumn{3}{|c|}{ New client/supplier } & \multicolumn{3}{|c|}{ Conference/trade fair } \\
\hline & $\mathrm{dy} / \mathrm{dx}$ & Std err & $\mathbf{P}>|\mathbf{Z}|$ & $\mathrm{dy} / \mathrm{dx}$ & Std err & $\mathbf{P}>|\mathbf{Z}|$ & $\mathrm{dy} / \mathrm{dx}$ & Std err & $\mathbf{P}>|\mathbf{Z}|$ \\
\hline $\begin{array}{l}\text { Predicted } \\
\text { probability }\end{array}$ & .301 & & & .153 & & & .147 & & \\
\hline $\begin{array}{l}\text { Nr trips/year: } \\
\text { Ref: 2-5 }\end{array}$ & & & & & & & & & \\
\hline 1 & $-0.111^{\star \star *}$ & 0.036 & 0.002 & 0.066 * & 0.035 & 0.060 & $0.091^{\star \star \star}$ & 0.032 & 0.005 \\
\hline $6-9$ & $0.123^{\star \star *}$ & 0.036 & 0.001 & $-0.041^{*}$ & 0.022 & 0.064 & $-0.093^{* \star *}$ & 0.018 & 0.000 \\
\hline $\begin{array}{l}10+ \\
\text { Length trip: } \\
\text { Ref: } 2-5\end{array}$ & $0.094^{\star \star *}$ & 0.031 & 0.002 & -0.030 & 0.021 & 0.150 & $-0.123^{\star \star *}$ & 0.018 & 0.000 \\
\hline $6-10$ days & 0.026 & 0.029 & 0.379 & 0.035 & 0.022 & 0.107 & -0.026 & 0.019 & 0.173 \\
\hline $11-20$ days & 0.053 & 0.039 & 0.181 & -0.008 & 0.027 & 0.762 & $-0.078^{* \star *}$ & 0.020 & 0.000 \\
\hline $\begin{array}{l}21 \text { days-12 mo. } \\
\text { Employer: } \\
\text { Ref: MNC }\end{array}$ & 0.074 & 0.046 & 0.105 & -0.010 & 0.033 & 0.769 & $-0.164^{\star \star \star}$ & 0.013 & 0.000 \\
\hline Gov/NGO/ univ & $-0.077^{\star}$ & 0.045 & 0.086 & 0.029 & 0.039 & 0.459 & $0.253^{* \star *}$ & 0.047 & 0.000 \\
\hline 100+ empl & 0.047 & 0.041 & 0.244 & 0.048 & 0.035 & 0.166 & 0.044 & 0.034 & 0.198 \\
\hline $\begin{array}{l}\text { SME (<100 empl) } \\
\text { Functional area: } \\
\text { Ref: sales \& mktg }\end{array}$ & $0.199^{\star \star \star}$ & 0.032 & 0.000 & $0.089^{\star \star \star}$ & 0.028 & 0.001 & -0.007 & 0.025 & 0.778 \\
\hline Strategy & $-0.135^{\star * *}$ & 0.031 & 0.000 & $-0.037^{\star}$ & 0.022 & 0.084 & -0.007 & 0.028 & 0.795 \\
\hline Production & 0.043 & 0.037 & 0.247 & $-0.130^{\star \star \star}$ & 0.018 & 0.000 & $-0.047^{*}$ & 0.026 & 0.071 \\
\hline Coordination & $-0.069^{*}$ & 0.040 & 0.089 & $-0.129^{\star \star \star}$ & 0.018 & 0.000 & $-0.065^{\star \star *}$ & 0.024 & 0.006 \\
\hline $\begin{array}{l}\text { Training } \\
\text { Field education } \\
\text { Ref: non-S\&E }\end{array}$ & -0.042 & 0.048 & 0.374 & $-0.091^{\star * *}$ & 0.022 & 0.000 & 0.006 & 0.035 & 0.866 \\
\hline Scientist & $-0.062^{\star}$ & 0.032 & 0.054 & 0.041 & 0.028 & 0.133 & $0.072^{\star \star \star}$ & 0.027 & 0.009 \\
\hline Engineer & -0.002 & 0.030 & 0.941 & 0.020 & 0.024 & 0.398 & -0.021 & 0.025 & 0.402 \\
\hline Female & -0.023 & 0.040 & 0.557 & $-0.071^{\star *}$ & 0.033 & 0.030 & $0.050^{\star \star}$ & 0.026 & 0.050 \\
\hline Foreign resident & -0.036 & 0.024 & 0.133 & $0.042^{\star *}$ & 0.019 & 0.024 & 0.011 & 0.018 & 0.552 \\
\hline $\begin{array}{l}\text { Sector dummy } \\
\text { Origin/destination }\end{array}$ & Yes & Yes & Yes & Yes & Yes & Yes & Yes & Yes & Yes \\
\hline dummy & Yes & Yes & Yes & Yes & Yes & Yes & Yes & Yes & Yes \\
\hline Airport dummy & Yes & Yes & Yes & Yes & Yes & Yes & Yes & Yes & Yes \\
\hline $\begin{array}{l}\text { Age group dummy } \\
\text { Education level }\end{array}$ & Yes & Yes & Yes & Yes & Yes & Yes & Yes & Yes & Yes \\
\hline dummy & Yes & Yes & Yes & Yes & Yes & Yes & Yes & Yes & Yes \\
\hline Owner dummy & Yes & Yes & Yes & Yes & Yes & Yes & Yes & Yes & Yes \\
\hline $\mathrm{Nr}$ observations & & & & & 1,827 & & & & \\
\hline Wald chi & & & & & 638.1 & & & & \\
\hline LL (model) & & & & & $-2,042.0$ & & & & \\
\hline Pseudo $\mathrm{R}^{2}$ & & & & & .1637 & & & & \\
\hline
\end{tabular}


Table 6 Binomial Probit Estimates - Coefficients

\begin{tabular}{|c|c|c|c|c|c|c|c|c|c|}
\hline & \multicolumn{3}{|c|}{ Within S-chain } & \multicolumn{3}{|c|}{ New client/supplier } & \multicolumn{3}{|c|}{ Conference/trade fair } \\
\hline & Coeff. & Std err & $\mathbf{P}>|\mathbf{Z}|$ & Coeff. & Std err & $\mathbf{P}>|\mathbf{Z}|$ & Coeff. & Std err & $\mathbf{P}>|\mathbf{Z}|$ \\
\hline \multicolumn{10}{|l|}{$\begin{array}{l}\text { Outcome eq. } 1 \text { - } \\
\text { knowledge } \\
\text { exchange } \\
\text { Nr trips/year: } \\
\text { Ref: } 2-5\end{array}$} \\
\hline 1 & -0.179 & 0.154 & 0.243 & -0.148 & 0.154 & 0.338 & -0.108 & 0.121 & 0.371 \\
\hline $6-9$ & $-0.318 * * *$ & 0.118 & 0.007 & $-0.272^{\star *}$ & 0.137 & 0.047 & -0.199 & 0.130 & 0.125 \\
\hline $10+$ & $-0.267^{\star * *}$ & 0.102 & 0.009 & $-0.249^{* *}$ & 0.114 & 0.029 & $-0.340^{\star \star *}$ & 0.112 & 0.002 \\
\hline \multicolumn{10}{|l|}{ Ref: $2-5$} \\
\hline $6-10$ days & -0.070 & 0.101 & 0.489 & 0.017 & 0.112 & 0.881 & -0.070 & 0.101 & 0.487 \\
\hline $11-20$ days & -0.150 & 0.125 & 0.231 & 0.062 & 0.143 & 0.664 & -0.128 & 0.130 & 0.322 \\
\hline 21 days-12 mo. & $-0.387^{\star \star *}$ & 0.147 & 0.009 & $-0.281^{*}$ & 0.161 & 0.081 & $-0.471^{\star \star *}$ & 0.161 & 0.003 \\
\hline \multicolumn{10}{|l|}{ Employer: } \\
\hline \multicolumn{10}{|l|}{ Ref: MNC } \\
\hline Gov/NGO/ univ & $0.294^{*}$ & 0.174 & 0.091 & 0.181 & 0.193 & 0.348 & $0.336^{\star \star}$ & 0.146 & 0.021 \\
\hline 100+ empl & 0.144 & 0.128 & 0.259 & -0.041 & 0.142 & 0.774 & 0.142 & 0.137 & 0.300 \\
\hline SME (<100 empl) & $-0.184^{*}$ & 0.109 & 0.093 & $-0.263^{\star \star}$ & 0.133 & 0.048 & -0.080 & 0.133 & 0.550 \\
\hline \multicolumn{10}{|l|}{ Functional area: } \\
\hline \multicolumn{10}{|l|}{ Ref: sales \& mktg } \\
\hline Strategy & $0.277^{\star \star}$ & 0.136 & 0.041 & $0.257^{\star}$ & 0.146 & 0.077 & $0.395^{\star \star \star}$ & 0.147 & 0.007 \\
\hline Production & 0.172 & 0.134 & 0.201 & 0.210 & 0.152 & 0.168 & 0.162 & 0.150 & 0.283 \\
\hline Coordination & $0.260^{*}$ & 0.151 & 0.085 & $0.289^{*}$ & 0.168 & 0.086 & 0.243 & 0.161 & 0.131 \\
\hline Training & $0.589^{\star \star \star}$ & 0.176 & 0.001 & $0.590^{\star \star \star}$ & 0.197 & 0.003 & $0.488^{\star * \star}$ & 0.169 & 0.004 \\
\hline \multicolumn{10}{|l|}{ Field education } \\
\hline \multicolumn{10}{|l|}{ Ref: non-S\&E } \\
\hline Scientist & $0.202^{\star}$ & 0.120 & 0.093 & 0.136 & 0.128 & 0.287 & 0.173 & 0.112 & 0.122 \\
\hline Engineer & 0.011 & 0.106 & 0.916 & 0.028 & 0.117 & 0.809 & 0.111 & 0.113 & 0.328 \\
\hline Female & 0.175 & 0.135 & 0.194 & 0.074 & 0.148 & 0.618 & 0.087 & 0.120 & 0.472 \\
\hline Foreign resident & 0.041 & 0.083 & 0.622 & 0.083 & 0.090 & 0.358 & -0.024 & 0.084 & 0.773 \\
\hline \multirow{4}{*}{\multicolumn{10}{|c|}{$\begin{array}{l}\text { Outcome eq. } 2 \text { - } \\
\text { Purpose of visit } \\
\text { Nr trips/year: } \\
\text { Ref: } 2-5\end{array}$}} \\
\hline & & & & & & & & & \\
\hline & & & & & & & & & \\
\hline & & & & & & & & & \\
\hline 1 & -0.148 & 0.147 & 0.316 & $0.305^{\star \star}$ & 0.151 & 0.044 & $0.335^{\star \star}$ & 0.136 & 0.014 \\
\hline $6-9$ & $0.212^{\star}$ & 0.110 & 0.053 & -0.210 & 0.141 & 0.136 & $-0.492^{\star \star \star}$ & 0.146 & 0.001 \\
\hline $10+$ & 0.083 & 0.097 & 0.396 & -0.173 & 0.120 & 0.148 & $-0.589^{\star \star \star}$ & 0.130 & 0.000 \\
\hline Ongoing trip & -0.006 & 0.109 & 0.953 & 0.038 & 0.127 & 0.763 & $0.451^{\star \star \star}$ & 0.113 & 0.000 \\
\hline \multirow{2}{*}{\multicolumn{10}{|c|}{$\begin{array}{l}\text { Length trip: } \\
\text { Ref: } 2-5\end{array}$}} \\
\hline & & & & & & & & & \\
\hline 6-10 days & 0.075 & 0.093 & 0.423 & 0.110 & 0.109 & 0.310 & 0.038 & 0.106 & 0.719 \\
\hline $11-20$ days & -0.006 & 0.114 & 0.960 & -0.190 & 0.140 & 0.176 & $-0.305^{\star *}$ & 0.146 & 0.036 \\
\hline 21 days-12 mo. & -0.081 & 0.129 & 0.528 & -0.244 & 0.172 & 0.155 & $-1.264^{\star \star \star}$ & 0.224 & 0.000 \\
\hline Employer: & & & & & & & & & \\
\hline \multicolumn{10}{|l|}{ Ref: MNC } \\
\hline Gov/NGO/ univ & 0.231 & 0.168 & 0.167 & $0.550^{\star \star \star}$ & 0.206 & 0.008 & $1.101^{\star \star \star}$ & 0.154 & 0.000 \\
\hline 100+ empl & $0.329^{\star \star \star}$ & 0.122 & 0.007 & $0.461^{\star \star \star}$ & 0.148 & 0.002 & $0.387^{\star *}$ & 0.153 & 0.011 \\
\hline SME (<100 empl) & $0.917^{\star \star \star}$ & 0.102 & 0.000 & $0.824^{\star \star \star}$ & 0.131 & 0.000 & $0.474^{\star \star \star}$ & 0.145 & 0.001 \\
\hline \multirow{2}{*}{\multicolumn{10}{|c|}{$\begin{array}{l}\text { Functional area: } \\
\text { Ref: sales \& mktg }\end{array}$}} \\
\hline & & & & & & & & & \\
\hline Strategy & $-0.589^{\star \star \star}$ & 0.125 & 0.000 & $-0.454^{\star \star \star}$ & 0.136 & 0.001 & $-0.281^{*}$ & 0.157 & 0.074 \\
\hline Production & -0.136 & 0.121 & 0.261 & $-0.875^{\star \star \star}$ & 0.151 & 0.000 & $-0.467^{\star \star \star}$ & 0.164 & 0.004 \\
\hline Coordination & $-0.498^{\star * *}$ & 0.143 & 0.000 & $-1.178^{\star \star *}$ & 0.195 & 0.000 & $-0.666^{\star \star \star}$ & 0.178 & 0.000 \\
\hline Training & -0.257 & 0.166 & 0.121 & $-0.706^{\star \star \star}$ & 0.200 & 0.000 & -0.129 & 0.180 & 0.473 \\
\hline Field education & & & & & & & & & \\
\hline
\end{tabular}




\begin{tabular}{|c|c|c|c|c|c|c|c|c|c|}
\hline $\begin{array}{l}\text { Ref: non-S\&E } \\
\text { Scientist }\end{array}$ & -0.017 & 0.114 & 0.881 & $0.289 * *$ & 0.134 & 0.031 & $0.219^{*}$ & 0.124 & 0.079 \\
\hline Engineer & 0.033 & 0.099 & 0.736 & 0.026 & 0.119 & 0.827 & -0.154 & 0.136 & 0.260 \\
\hline Female & -0.072 & 0.131 & 0.580 & $-0.338^{* *}$ & 0.167 & 0.044 & 0.150 & 0.134 & 0.265 \\
\hline $\begin{array}{l}\text { Sector dummy } \\
\text { Origin/destination }\end{array}$ & Yes & Yes & Yes & Yes & Yes & Yes & Yes & Yes & Yes \\
\hline dummy & Yes & Yes & Yes & Yes & Yes & Yes & Yes & Yes & Yes \\
\hline Airport dummy & Yes & Yes & Yes & Yes & Yes & Yes & Yes & Yes & Yes \\
\hline $\begin{array}{l}\text { Age group dummy } \\
\text { Education level }\end{array}$ & Yes & Yes & Yes & Yes & Yes & Yes & Yes & Yes & Yes \\
\hline dummy & Yes & Yes & Yes & Yes & Yes & Yes & Yes & Yes & Yes \\
\hline Owner dummy & Yes & Yes & Yes & Yes & Yes & Yes & Yes & Yes & Yes \\
\hline Atrho & -0.213 * & 0.054 & 0.000 & $-0.275^{\star}$ & 0.067 & 0.000 & $0.212^{* \star *}$ & 0.061 & 0.000 \\
\hline Rho & $-0.210^{*}$ & 0.052 & & $-0.268^{*}$ & 0.062 & & $0.209^{\star \star *}$ & 0.058 & \\
\hline Nr observations & & 1,176 & & & 946 & & & 1,029 & \\
\hline Wald chi & & 228.6 & & & 229.6 & & & 370.4 & \\
\hline LL (model) & & $-1,342.4$ & & & -982.8 & & & $1,101.0$ & \\
\hline Prob > chi2 & & 0.000 & & & 0.000 & & & 0.000 & \\
\hline
\end{tabular}

Table 7 Marginal Effects of Conditional Probability - Biprobit ESTIMATIONS

\begin{tabular}{|c|c|c|c|c|c|c|c|c|c|}
\hline \multirow{3}{*}{$\begin{array}{l}\text { Variable } \\
\text { Predicted } \\
\text { probability }\end{array}$} & \multicolumn{3}{|c|}{ Within S-chain } & \multicolumn{3}{|c|}{ New client/supplier } & \multicolumn{3}{|c|}{ Conference/trade fair } \\
\hline & $\mathrm{dy} / \mathrm{dx}$ & Std err & $\mathbf{P}>|\mathbf{Z}|$ & $\mathrm{dy} / \mathrm{dx}$ & Std err & $\mathbf{P}>|\mathbf{Z}|$ & $\mathrm{dy} / \mathrm{dx}$ & Std err & $\mathbf{P}>|\mathbf{Z}|$ \\
\hline & .181 & & & .151 & & & .471 & & \\
\hline $\begin{array}{l}\text { Nr trips/year: } \\
\text { Ref: 2-5 }\end{array}$ & & & & & & & & & \\
\hline 1 & -.050 & .035 & .157 & -.020 & .035 & .573 & -.063 & .048 & .190 \\
\hline $6-9$ & $-.071^{\star \star \star}$ & .026 & .008 & $-.068^{\star * *}$ & .026 & .009 & -.049 & .052 & .345 \\
\hline $\begin{array}{l}10+ \\
\text { Length trip: } \\
\text { Ref: } 2-5\end{array}$ & $-.066^{\star \star \star}$ & .025 & .009 & $.065^{\star \star \star}$ & .024 & .008 & $-.099 * \star$ & .045 & .028 \\
\hline $6-10$ days & -.016 & .026 & .553 & .009 & .027 & .721 & -.031 & .040 & .448 \\
\hline $11-20$ days & -.038 & .030 & .204 & .005 & .035 & .877 & -.032 & .052 & .532 \\
\hline $\begin{array}{l}21 \text { days-12 mo. } \\
\text { Employer: } \\
\text { Ref: MNC }\end{array}$ & $-.092^{\star \star \star}$ & .029 & .001 & $-.070 \star \star$ & .029 & .019 & -.104 & .065 & .109 \\
\hline Gov/NGO/ univ & $.098^{\star}$ & .057 & .085 & .078 & .056 & .167 & .072 & .061 & .233 \\
\hline $100+$ empl & .054 & .038 & .160 & .013 & .036 & .722 & .034 & .055 & .533 \\
\hline $\begin{array}{l}\text { SME (<100 empl) } \\
\text { Functional area: } \\
\text { Ref: sales \& mktg }\end{array}$ & -.015 & .030 & .612 & -.023 & .032 & .475 & -.060 & .054 & .262 \\
\hline Strategy & .053 & .040 & .185 & .040 & .038 & .289 & $.176^{\star \star \star}$ & .058 & .002 \\
\hline Production & .042 & .038 & .272 & .005 & .039 & .894 & .095 & .061 & .117 \\
\hline Coordination & .052 & .046 & .253 & .007 & .044 & .873 & $.141^{\star *}$ & .064 & .028 \\
\hline $\begin{array}{l}\text { Training } \\
\text { Field education } \\
\text { Ref: non-S\&E }\end{array}$ & $.175^{\star \star \star}$ & .064 & .006 & $.125^{*}$ & .066 & .060 & $.203^{\star \star \star}$ & .065 & .002 \\
\hline Scientist & .056 & .036 & .115 & .050 & .034 & .147 & .057 & .046 & .213 \\
\hline Engineer & .004 & .028 & .879 & .008 & .028 & .771 & .054 & .045 & .232 \\
\hline Female & .044 & .036 & .224 & .001 & .035 & .980 & .026 & .049 & .596 \\
\hline Foreign resident & .011 & .022 & .622 & .020 & .022 & .359 & -.009 & .034 & .773 \\
\hline Ongoing trip & -.0002 & .004 & .953 & .002 & .006 & .764 & $-.028^{* * *}$ & .011 & .009 \\
\hline
\end{tabular}

